\title{
Blocking of Bacteriophage Receptor Sites by Concanavalin A
}

\author{
By A. R. ARCHIBALD AND HILARY E. COAPES \\ Microbiological Chemistry Research Laboratory, University of Newcastle upon Tyne, \\ Newcastle upon Tyne, $N E_{\mathrm{I}} 7 R U$
}

(Received 4 July 1972)

Teichoic acids form part of the bacteriophage receptor sites in the walls of several Grampositive bacteria (Young, 1967; Coyette \& Ghuysen, I968; Chatterjee, 1969). Concanavalin A interacts with teichoic acids that possess $\alpha$-linked glucosyl or $N$-acetyl-glucosaminyl substituents (Archibald \& Coapes, 197I ; Reeder \& Ekstedt, 197I) and so might be expected to prevent access of bacteriophages to their receptor sites in walls which contain such teichoic acids. We have examined the influence of Concanavalin A on the binding of bacteriophage K (Ralston, Baer, Lieberman \& Kreuger, I957) to Staphylococcus aureus strains 3528 , AI and $\mathrm{H}$, the walls of which contain exclusively $\alpha$-, exclusively $\beta$ - and predominantly $\beta$-, with some $\alpha$-, $N$-acetyl-glucosaminyl substituents respectively (Baddiley, Buchanan, Martin \& RajBhandary, I962; Nathenson \& Strominger, I962; Davison, Baddiley, Hofstad, Losnegard \& Oeding, I964). The action of Concanavalin A on the binding of bacteriophage SP-50 (Foldes \& Trautner, 1964) to Bacillus subtilis strains 3610 and w-23, the wall teichoic acids of which contain respectively $\alpha$ - and $\beta$-linked glucosyl substituents (Chin, Burger \& Glaser, I966; Doyle \& Birdsell, I972) has also been studied. Additionally we have studied the effect of Concanavalin A on the infection of $B$. subtilis strains $\mathrm{W}-23$ and $36 \mathrm{I}$ o by bacteriophage SP-50 and of $S$. aureus strains 3528 and $\mathrm{H}$ by the typing bacteriophages 53 and $52 \mathrm{~A}$ respectively.

\section{METHODS}

Bacteriophages. Bacteriophage-SP-50, obtained from Dr T. A. Trautner, was propagated on Bacillus subtilis W-23; bacteriophage K, obtained from Dr E. Asheshov, was propagated on Staphylococcus aureus 9318 ; bacteriophages $52 \mathrm{~A}$ and 53, obtained from Mr G. Fenwick, were propagated on $S$. aureus strains $52 \mathrm{~A}$ and 3528 respectively.

The bacteriophages were re-isolated from single plaques and then propagated by the soft agar overlay method (Adams, I959). The bacteriophages were eluted from the plates with tryptic soy broth, filtered through a $0.45 \mathrm{~nm}$ Millipore filter and assayed in soft agar layers containing the propagating strain $\left(2 \times 10^{7}\right.$ bacteria/ml $)$ grown for $5 \mathrm{~h}$ at $37^{\circ} \mathrm{C}$. The yield of plaque-forming units (p.f.u.) was between $5 \times 10^{9} / \mathrm{ml}$ and $2 \times 10^{10} / \mathrm{ml}$.

Antiserum. Rabbit antisera were prepared against the above bacteriophages and diluted so that under the test conditions over $99.9 \%$ of the bacteriophages were inactivated.

Growth of bacteria. Bacteria were grown in NBS medium containing Oxoid Nutrient broth $(2.5 \%, \mathrm{w} / \mathrm{v})$, sodium succinate $(\mathrm{I} \%, \mathrm{w} / \mathrm{v})$ and magnesium sulphate $(0.0 \mathrm{I} \mathrm{M})$. Flasks $(50 \mathrm{ml})$ containing this medium $(25 \mathrm{ml})$ were inoculated with $0.2 \mathrm{ml}$ of an overnight culture, grown in the same medium, and incubated with aeration at $37^{\circ} \mathrm{C}$ for $5 \mathrm{~h}$ when the bacilli attained $\mathrm{IO}^{9}$ organisms $/ \mathrm{ml}$ and the staphylococci $2 \times \mathrm{IO}^{9} / \mathrm{ml}$. Preliminary studies showed that this medium gave only a slight precipitate with Concanavalin A and did not inhibit the precipitation of glycogen by the lectin. 
Concanavalin A. Water-soluble Concanavalin A was prepared by the method of Olson \& Leiner (1967). A stock solution was prepared containing Concanavalin A (I g/10 ml buffer of the following composition: $\mathrm{Na}_{2} \mathrm{HPO}_{4}, 7 \mathrm{~g} ; \mathrm{KH}_{2} \mathrm{PO}_{4}, 3 \mathrm{~g} ; \mathrm{NaCl}, 5 \mathrm{~g}$; $0 . \mathrm{I} \mathrm{M}-\mathrm{MgSO}_{4}$, Io $\mathrm{ml}$; O.0I $\mathrm{M}-\mathrm{CaCl}_{2}$, IO $\mathrm{ml}$; water, I l). This stock solution was diluted into NBS medium before use.

Action of Concanavalin A on the binding of bacteriophages by Bacillus subtilis and Staphylococcus aureus strains. Samples ( $0.1 \mathrm{ml}$ containing approximately $7 \times 10^{7}$ bacteria) of the $5 \mathrm{~h}$ cultures suitably diluted in NBS medium at $37^{\circ} \mathrm{C}$ were placed in plugged sterile tubes $(\mathrm{I} 6 \times 150 \mathrm{~mm})$ held in a water bath at $37^{\circ} \mathrm{C}$. Portions $(0.1 \mathrm{ml})$ of Concanavalin A solution $\left(0.5 \%\right.$ or I \%) were added and the mixtures incubated at $37^{\circ} \mathrm{C}$ for $5 \mathrm{~min}$ before being mixed with bacteriophage ( $0^{\circ} \mathrm{I} \mathrm{ml}$ containing approximately $7 \times 10^{5}$ p.f.u.). The mixture was incubated at $37^{\circ} \mathrm{C}$ for a further $15 \mathrm{~min}$ before adding a sample (O.I ml) to $9.9 \mathrm{ml}$ of NBS medium at $37^{\circ} \mathrm{C}$. It was filtered through a $0.45 \mathrm{~nm}$ Millipore filter to remove bacteria and adsorbed bacteriophage and samples (0.I $\mathrm{ml}$ ) of the filtrate and of a tenfold dilution of the filtrate were assayed for plaque-forming units.

In control experiments bacteria were first incubated with $0.1 \mathrm{ml}$ of Concanavalin A (I \%) plus $\alpha$-methyl glucoside ( $\%$, Sigma Chemical Co., London) or with NBS medium ( $0.1 \mathrm{ml})$. Further controls were set up to determine the number of bacteriophage and bacteria added to the mixtures. Plaque and colony counts were determined in duplicate, about 200 plaques or colonies were counted per plate except where more than $90 \%$ of the bacteriophage were adsorbed. The experiments were repeated giving closely similar results. Under the above conditions incubation with Concanavalin A for $20 \mathrm{~min}$ had no significant effect on the number of colonies formed, showing that agglutination was not detectable in this time at the low cell densities used.

The action on Concanavalin A on the infection of Bacillus subtilis and Staphylococcus aureus strains by bacteriophages. Samples ( $0.1 \mathrm{ml}$ containing $7 \times 10^{7}$ bacteria) of $5 \mathrm{~h}$ cultures diluted into NBS medium at $37{ }^{\circ} \mathrm{C}$ were placed in sterile plugged tubes and mixed with samples $(0.1 \mathrm{ml})$ of warm medium alone or with $0.5 \%$ Concanavalin A plus and minus $\alpha$-methyl glucoside as above. After incubation at $37^{\circ} \mathrm{C}$ for $5 \mathrm{~min}$, bacteriophage (0.1 $\mathrm{ml}$ containing approximately $10^{6}$ p.f.u.) was added followed, after incubation for $5 \mathrm{~min}$, by diluted antiserum $(0.7 \mathrm{ml})$. After incubation for a further $5 \mathrm{~min}$ to inactive unadsorbed bacteriophage samples $(0.1 \mathrm{ml})$ were serially diluted into NBS medium at $37^{\circ} \mathrm{C}$ and duplicate portions $(0.1 \mathrm{ml})$ were assayed for infectious centres by the soft agar overlay method.

In control experiments the numbers of bacteria and bacteriophage added to the mixtures were determined. Pre-incubation with Concanavalin A did not inactivate any of the phages studied and again none of the bacteria were agglutinated by incubation with Concanavalin $A$ under these conditions. Repeat experiments gave closely similar results although the values obtained were influenced by slight differences in the concentrations of bacteria and bacteriopage in separate experiments.

\section{RESULTS AND DISCUSSION}

All three strains of staphylococci adsorbed over $90 \%$ of the bacteriophage originally present in the mixtures in $15 \mathrm{~min}$ of incubation. Pre-incubation with Concanavalin A had little effect on the adsorption of bacteriophage K by Staphylococcus aureus A I but markedly reduced the adsorption by $S$. aureus 3528 (Table I). $\alpha$-Methyl glucoside prevented this effect of Concanavalin A. The blocking is therefore due to the specific interaction of Concanavalin A with the sugar residues on the bacterial surface. These groups are almost certainly the $\alpha$ - $N$-acetyl-glucosaminyl substituents of the wall teichoic acid which is the only 
Table I. Influence of Concanavalin A on the interaction of bacteriophage K with Staphylococcus aureus and bacteriophage SP-50 with Bacillus subtilis

Samples ( $0.1 \mathrm{ml}$, containing approximately $7 \times 10^{7}$ bacteria) were incubated in medium with Concanavalin A or Concanavalin A plus $\alpha$-methyl glucoside as shown and then mixed with bacteriophages ( $0.1 \mathrm{ml}$ ). After incubation for $15 \mathrm{~min}$ bacteria and adsorbed bacteriophages were removed by filtration and unadsorbed bacteriophages were counted. Conditions were as described in text.

\begin{tabular}{|c|c|c|c|c|}
\hline \multirow[b]{2}{*}{ Bacteria } & \multirow[b]{2}{*}{$\begin{array}{l}\text { Pre-incubation in medium with } \\
\text { additions shown }\end{array}$} & \multicolumn{2}{|c|}{ No. $\left(\times 10^{-4}\right)$ phage in: } & \multirow{2}{*}{$\begin{array}{l}\text { Phage } \\
\text { adsorbed } \\
(\%)\end{array}$} \\
\hline & & $\begin{array}{l}\text { Incubation } \\
\text { mixture }\end{array}$ & Filtrate & \\
\hline Staphylococcus aureus A I & $\begin{array}{l}\text { None } \\
0.25 \% \text { Con A } \\
0.50 \% \text { Con A } \\
0.50 \% \text { Con A }+\alpha \text {-methyl glucoside }\end{array}$ & $\begin{array}{l}66 \pm 3 \\
66 \pm 3 \\
66 \pm 3 \\
66 \pm 3\end{array}$ & $\begin{array}{l}0.96 \pm 0.27 \\
5.9 \pm 0.3 \\
8 \cdot 9 \pm 0.4 \\
0.92 \pm 0.27\end{array}$ & $\begin{array}{l}99 \\
91 \\
87 \\
99\end{array}$ \\
\hline S. aureus 3528 & $\begin{array}{l}\text { None } \\
0.25 \% \text { Con A } \\
0.50 \% \text { Con A } \\
0.50 \% \text { Con A }+\alpha \text {-methyl glucoside }\end{array}$ & $\begin{array}{l}63 \pm 3 \\
63 \pm 3 \\
63 \pm 3 \\
63 \pm 3\end{array}$ & $\begin{array}{l}3 \cdot 7 \pm 0 \cdot 2 \\
48 \pm 2 \\
59 \pm 3 \\
3 \cdot 4 \pm 0 \cdot 2\end{array}$ & $\begin{array}{r}94 \\
24 \\
6 \\
95\end{array}$ \\
\hline S. aureus $\mathrm{H}$ & $\begin{array}{l}\text { None } \\
0.25 \% \text { Con A } \\
0.50 \% \text { Con A } \\
0.50 \% \text { Con A }+\alpha \text {-methyl glucoside }\end{array}$ & $\begin{array}{l}63 \pm 3 \\
63 \pm 3 \\
63 \pm 3 \\
63 \pm 3\end{array}$ & $\begin{array}{l}4 \cdot 2 \pm 0 \cdot 3 \\
8 \cdot 2 \pm 0 \cdot 3 \\
27 \pm 3 \\
3 \cdot 9 \pm 2\end{array}$ & $\begin{array}{l}93 \\
87 \\
57 \\
94\end{array}$ \\
\hline Bacillus subtilis w23 & $\begin{array}{l}\text { None } \\
0.25 \% \text { Con A } \\
0.25 \% \text { Con A }+\alpha \text {-methyl glucoside }\end{array}$ & $\begin{array}{l}67 \pm 3 \\
67 \pm 3 \\
67 \pm 3\end{array}$ & $\begin{array}{l}30 \pm 2 \\
29 \pm 2 \\
30 \pm 2\end{array}$ & $\begin{array}{l}55 \\
57 \\
55\end{array}$ \\
\hline B. subtilis $36 \mathrm{ro}$ & $\begin{array}{l}\text { None } \\
0.25 \% \text { Con A } \\
0.25 \% \text { Con A }+\alpha \text {-methyl glucoside }\end{array}$ & $\begin{array}{l}67 \pm 3 \\
67 \pm 3 \\
67 \pm 3\end{array}$ & $\begin{array}{l}38 \pm 3 \\
61 \pm 3 \\
42 \pm 2\end{array}$ & $\begin{array}{r}43 \\
9 \\
37\end{array}$ \\
\hline
\end{tabular}

known surface component which can intereact with Concanavalin $\mathrm{A}$. This conclusion is strengthened by the failure of Concanavalin A to affect markedly the adsorption by strain A I, the wall teichoic acid of which is reported to contain only $\beta$ - $N$-acetyl-glycosaminyl substituents. This organism may however contain a small proportion of $\alpha$-linked $N$-acetylglucosaminyl substituents since pre-incubation in $0.5 \%$ Concanavalin A reduced bacteriophage binding by approximately 10 \%, an effect which was reversed by the presence of $\alpha$-methyl glucoside indicating that the blocking is not due to non-specific adsorption of Concanavalin A. Approximately $15 \%$ of the $\mathrm{N}$-acetyl-glucosaminyl substituents of the wall teichoic acid of $S$. aureus $\mathrm{H}$ have the $\alpha$-anomeric configuration. Pre-incubation in $0.5 \%$ Concanavalin A blocked adsorption of bacteriophage by this organism by approximately $40 \%$, a value which is intermediate between that of $10 \%$ obtained with strain AI and that of approximately $90 \%$ obtained with strain 3528 , the wall teichoic acid of which contains exclusively $\alpha$-linked $N$-acetyl-glucosaminyl substituents. Under the conditions described the action of Concanavalin $A$ on adsorption of bacteriophage by these three strains of $S$. aureus correlates well with what would be forecast on the basis of the known structures of the wall teichoic acids of the organisms. Similar results were obtained with Bacillus subtilis strains W-23 and 36Io. Pre-incubation with Concanavalin A had little effect on bacteriophage adsorption by strain $\mathrm{W}-23$ but blocked adsorption by strain 3610 by $80 \%$. This blocking was also reversed by $\alpha$-methyl glucoside (Table I) and so was specifically due to the $\alpha$-glucosyl substituents of the wall teichoic acid; in strain $\mathrm{w}-23$ the wall teichoic acid contains only $\beta$-glucosyl substituents. Doyle \& Birdsell (1972) have recently referred to 
unpublished results which show that Concanavalin A blocks the phage receptor sites in walls of $B$. subtilis 168 , the teichoic acid of which is similar to that of strain 3610 .

The influence of Concanavalin A on bacteriophage infection was examined directly by neutralizing unadsorbed bacteriophage by the addition of antiserum and counting the infected organisms. In these experiments the bacteria were incubated with bacteriophage for only $5 \mathrm{~min}$ and the percentage of bacteriophage causing infection varied in different systems from $43 \%$ to $92 \%$. On incubation with Bacillus subtilis strain $3610,49 \%$ of the added bacteriophage SP-50 gave rise to infective centres but this value was reduced to $3 \%$ after pre-incubation with $0.25 \%$ Concanavalin A, whereas after pre-incubation with Concanavalin A plus $\alpha$-methyl glucoside $33 \%$ of the added bacteriophage gave rise to infective centres. The corresponding values for strain w-23 were $49 \%, 44 \%$ and $44 \%$ showing that Concanavalin A does not block infection in this organism. On incubation with Staphylococcus aureus $3528,43 \%$ of the added bacteriophage 53 gave infective centres. This value was reduced to $6 \%$ on pre-incubation of the cells with Concanavalin A and to $32 \%$ on incubation with Concanavalin A and $\alpha$-methyl glucoside. With $S$. aureus $\mathrm{H}$ and bacteriophage $52 \mathrm{~A}$ the corresponding values were $92 \%, 69 \%$ and $78 \%$. Thus in the presence of Concanavalin A infection of strain 3528 by bacteriophage 53 is specifically inhibited by over $50 \%$ whereas infection of strain $\mathrm{H}$ is inhibited by less than $10 \%$. These results correlate well with the adsorption studies and both methods show that Concanavalin A specifically blocks adsorption of the bacteriophage to those organisms with wall teichoic acids in which the sugar substituents have the $\alpha$-anomeric configuration but has no action on adsorption of phage to organisms in which these substituents have the $\beta$-configuration. The results obtained with the three strains of $S$. aureus suggest that these procedures might form the basis for a correlation between the bacteriophage and serological typing of staphylococci. After removal of excess Concanavalin A, determination of the increase in infection or phage binding by cells coated with Concanavalin A might be used to study synthesis of new wall material.

We wish to thank Mr K. Glassey for technical assistance and the Medical Research Council for financial support.

\section{REFERENCES}

Adams, M. H. (1959). Bacteriophages, pp. 450-45I. New York: Interscience Publishers Inc.

Archibald, A. R. \& CoAPEs, H. E. (197I). The interaction of Concanavalin A with teichoic acids and bacterial cell walls. Biochemical Journal r23, 665-667.

Baddiley, J., Buchanan, J. G., Martin, R. O. \& RajBhandary, U. L. (1962). Teichoic acid from the walls of Staphylococcus aureus $\mathrm{H}$. Location of phosphate and alanine residues. Biochemical Journal $\mathbf{8 5}$, 49-55.

Chatterjee, A. N. (1969). Use of bacteriophage resistant mutants to study the nature of the bacteriophage receptor site of Staphylococcus aureus. Journal of Bacteriology 98, 519-527.

Chin, T., Burger, M. M. \& Glaser, L. (I966). Synthesis of teichoic acids. VI. The formation of multiple wall polymers in Bacillus subtilis w-23. Archives of Biochemistry and Biophysics $\mathbf{1 r 6 , 3 5 8 - 3 6 7 .}$

Coyette, J. \& GHuysen, J. M. (1968). Structure of the cell wall of Staphylococcus aureus strain Copenhagen. IX. Teichoic acid and phage absorption. Biochemistry 7, 2385-2389.

Davison, A. L., Baddiley, J., Hofstad, T., Losnegard, N. \& Oeding, P. (1964). Teichoic acids in the walls of Staphylococci. Serological investigations on teichoic acids from the walls of Staphylococci. Nature, London 202, 872-874.

Doyle, R. J. \& Birdsell, D. C. (1972). Interaction of Concanavalin A with the cell wall of Bacillus subtilis. Journal of Bacteriology xo9, 652-658.

Foldes, J. \& Trautner, T. A. (I964). Infectious DNA from a newly isolated B. subtilis phage. Zeitschrift für Vererbungslehre $95,57-65$. 
Nathenson, S. C. \& Strominger, J. L. (I962). Enzymatic synthesis and immunochemistry of $N$-acetylglucosaminyl linkages in teichoic acids of Staphylococcus aureus strains. Journal of Biological Chemistry 237, 3839-384I.

Olson, M. O. J. \& LIENER, I. E. (1967). Some physical and chemical properties of Concanavalin A, the phytohaemagglutinin of the Jack Bean. Biochemistry 6, 105-III.

Ralston, D. J., Baer, B. S., Lieberman, M. \& Kreuger, A. P. (1957). Lysis-from-without of S. aureus K, by the combined action of phage and virolysin. Journal of General Physiology 4I, 343-358.

REEDER, W. J. \& Ekstedt, R. D. (I97I). Study of the interaction of Concanavalin A with Staphylococcal teichoic acids. Journal of Immunology ro6, 334-340.

YouNG, F. E. (1967). Requirement of glucosylated teichoic acid for adsorption of phage in B. subtilis 168 . Proceedings of the National Academy of Sciences of the United States of America 58, 2377-2383. 